\title{
DETEKSI PLAGIASI DOKUMEN SKRIPSI MAHASISWA MENGGUNAKAN METODE N-GRAMS DAN WINNOWING
}

\author{
Fitri Ratna Ning Wulan \\ Fakultas Sains dan Teknologi, Program Studi Sistem Informasi \\ Universitas Islam Negeri Sunan Ampel Surabaya \\ Email: fitriratna96@gmail.com \\ Anang Kunaefi \\ Fakultas Sains dan Teknologi, Program Studi Sistem Informasi \\ Universitas Islam Negeri Sunan Ampel Surabaya \\ Email: akunaefi@uinsby.ac.id \\ Andhy Permadi \\ Fakultas Sains dan Teknologi, Program Studi Sistem Informasi \\ Universitas Islam Negeri Sunan Ampel Surabaya \\ Email: andhy@uinsby.ac.id
}

\begin{abstract}
ABSTRAK
Salah satu tantangan dalam bidang akademik adalah mencegah maraknya aktivitas plagiarisme. Salah satu cara yang bisa dilakukan adalah dengan melakukan deteksi dini plagiasi terhadap karya mahasiswa terutama skripsi. Penerapan deteksi indikasi plagiarisme menggunakan metode $n$-grams dan winnowing merupakan tujuan dari penelitian ini, dan menemukan nominal $n$ yang efektif. Kata yang ada dalam dokumen skripsi direpresentasikan dalam bentuk hash, lalu dilakukan seleksi menggunakan algoritma winnowing untuk menentukan fingerprint dari dokumen yang akan disimpan dalam basis data. Pengujian dilakukan dengan menggunakan sampel dokumen skripsi mahasiswa. Hasil akhir dari penelitian menunjukkan bahwa sistem dapat mendeteksi adanya plagiasi menurut kesamaan kata secara konsisten berdasarkan beberapa skenario pengujian yang dijalankan, nominsl $n$ yang paling efektif dalam deteksi kesamaan kata yaitu $n=7$ dengan prosentase 3,07\% berdasarkan selisih antara pengujian menggunakan sistem dan pengujian manual.
\end{abstract}

Kata kunci: plagiarisme; hash; n-grams; fingerprint; winnowing.

\begin{abstract}
One of the challenges in the academic field is to prevent the rampant plagiarism activity. One way that can be done is to make early detection of plagiarism on the work of students, especially thesis. Implementation of the detection for plagiarism using n-grams and winnowing method are the aims of this study, and finding the most effective n-grams value. The word in the thesis document is represented in the form of hash, then some of them were selected using the winnowing algorithm to determine the fingerprint of the document to be stored in the database. The test was carried out using a thesis document. The final results of this study indicate that the system is able to detect the presence of plagiarism based on similarity of words based on several test scenarios that are run, and the most effective $n$ value used to detect document similarity is $n=7$ with the percentage difference (accuracy) between system testing and testing the manual is $3.07 \%$.
\end{abstract}

Keywords: plagiarism; hash; n-grams; fingerprint; winnowing.

\section{PENDAHULUAN}

Pada lingkup pendidikan plagiarisme marak dilakukan mahasiswa, diantaranya copy paste yang dilakukan saat pengerjaan tugas baik berasal dari internet maupun hasil karya orang lain. Hal tersebut juga memicu tindakan plagiarisme pada penulisan skripsi mahasiswa. Pendeteksian kesamaan kata pada dokumen merupakan salah satu langkah untuk mencegah plagiarisme, tetapi membutuhkan waktu lama ketika pengecekan dengan cara manual. Deteksi kesamaan kata dapat dilakukan menggunakan algoritma yang memperhatikan tinggi akurasi sistem saat mendeteksi (1). Kecepatan dan efisiensi waktu merupakan 
kelebihan dari penggunaan sistem deteksi plagiarisme dalam membantu pengecekan dokumen skripsi. Deteksi kesamaan kata mempunyai beberapa kriteria, yaitu : tanda spasi dan huruf kapital tidak berpengaruh, menghilangkan kata yang tidak relevan, tidak terpengaruh pada letak kata (2).

Ada beberapa algoritma yang digunakan dalam mendeteksi kemiripan kata, diantaranya algoritma $n$ grams yang menggunakan nilai $n$. Karakter yang ada pada teks digunakan untuk mengetahui tingkat kemiripan dengan panjang sesuai $n$, posisi karakter yang berbeda tidak menjadi hambatan dalam mendeteksi kemiripan kata (3). Kesalahan penulisan yang tidak berpengaruh pada pendeteksian menjadi keunggulan dari algoritma $n$-grams (1). Hal yang berpengaruh pada proses deteksi kesamaan yaitu panjang $n$, sehingga belum didapatkan nilai $n$ yang paling efektif dalam deteksi kesamaan kata.

Langkah selanjutnya setelah menggunakan algoritma n-grams dapat menggunakan algoritma winnowing, algoritma yang digunakan dalam mengecek kesamaan kata atau document fingerprinting (4). Fingerprint kata digunakan saat mengecek kesamaan kata. Penelitian sebelumnya yang dilakukan oleh Setiawan juga menggunakan algoritma winnowing dalam mendeteksi plagiarisme berdasarkan judul dan abstrak skripsi pada STMIK Budidarma (5).

Penelitian yang dilakukan oleh Dillak menggunakan metode $n$-grams dan winnowing untuk mendeteksi plagiarisme serta perhitungan kesamaan dengan rumus cosine similarity untuk mendapatkan prosentase kesamaan. Hasil penelitian tersebut sistem yang dibangun menggunakan bahasa pemrograman Java mampu mendeteksi kemiripan dengan cara membandingkan satu file uji dan satu file pembanding (1).

Penelitian yang dilakukan oleh Lisangan menggunakan algoritma $n$-grams dengan $n=3,4,5,6$, dan 7 dalam mendeteksi plagiarisme pada tugas mahasiswa, pada penelitian tersebut membandingkan satu file uji dengan banyak file pembanding dengan menghitung prosentase kemiripan menggunakan perhitungan Sorensen Dice Coefficient. Pada penelitian tersebut proses deteksi dilakukan dimulai dari menghapus tanda baca dan spasi pada teks kemudian merubah teks menjadi rangkaian n-grams tanpa dilakukan proses stemming. Hasil penelitian tersebut yaitu mendapatkan rata-rata selisih relevansi setiap $n$ (3).

Penelitian yang dilakukan oleh Purwitasari membahas tentang deteksi kalimat yang sama. Penelitian tersebut menggunakan algoritma $n$-grams dan winnowing. Hasil penelitian dengan sistem yang dibangun menggunakan bahasa pemrograman Java, sistem mampu mendeteksi persamaan kalimat dengan indikator nilai $n$, nilai b (bilangan prima), nilai w dan threshold. Pengujian dilakukan secara one to one, sehingga mempengaruhi waktu eksekusi (6).

Penelitian yang dilakukan oleh Wibowo membahas tentang penerapan algoritma winnowing untuk mendeteksi kemiripan teks pada tugas akhir mahasiswa dengan objek dokumen tugas akhir mahasiswa Univeristas Dian Nuswantoro. Penelitian tersebut menggunakan metode $n$-grams, winnowing dan jaccard coefficient untuk mendapatkan prosentase kemiripan teks. Hasil penelitian tersebut yaitu sistem yang dibangun mampu mendeteksi kemiripan teks dengan nilai $n=6$ dan nilai $n$ dan $w$ yang berbeda, menunjukkan bahwa semakin besar nilai $n$ maka semakin rendah tingkat kemiripan teks, sebaliknya semakin kecil nilai $n$ maka semakin tinggi tingkat kemiripan teks, tetapi hal tersebut tidak membuktikan bahwa hasil yang didapatkan akurat (4).

Penelitian selanjutnya yang dilakukan oleh Setiawan membahas tentang implementasi algoritma winnowing dalam mendeteksi kemiripan judul skripsi pada STMIK Budidarma. Penelitian tersebut menggunakan metode $n$-grams, winnowing dan jaccard coefficient untuk mendeteksi kemiripan judul dengan objek uji judul dan abstrak skripsi mahasiswa yang akan mengajukan judul skripsi. Pengujian pada penelitian tersebut membandingkan judul dan abstrak skripsi dengan judul dan abstrak skripsi yang sudah ada. Hasil penelitian tersebut didapatkan prosentase kemiripan judul dan abstrak skripsi dengan nilai $n$ yang sudah ditentukan (5).

Adanya sistem yang menerapkan algoritma $n$-grams dan winnowing untuk pendeteksian kemiripan kata diharapkan bisa didapatkan nilai $n$ paling efektif dalam deteksi kesamaan kata dalam dokumen.

\section{METODOLOGI PENELITIAN}

Penelitian ini mempunyai alur untuk menyelesaikan penelitian, seperti gambar 1 sebagai berikut: 


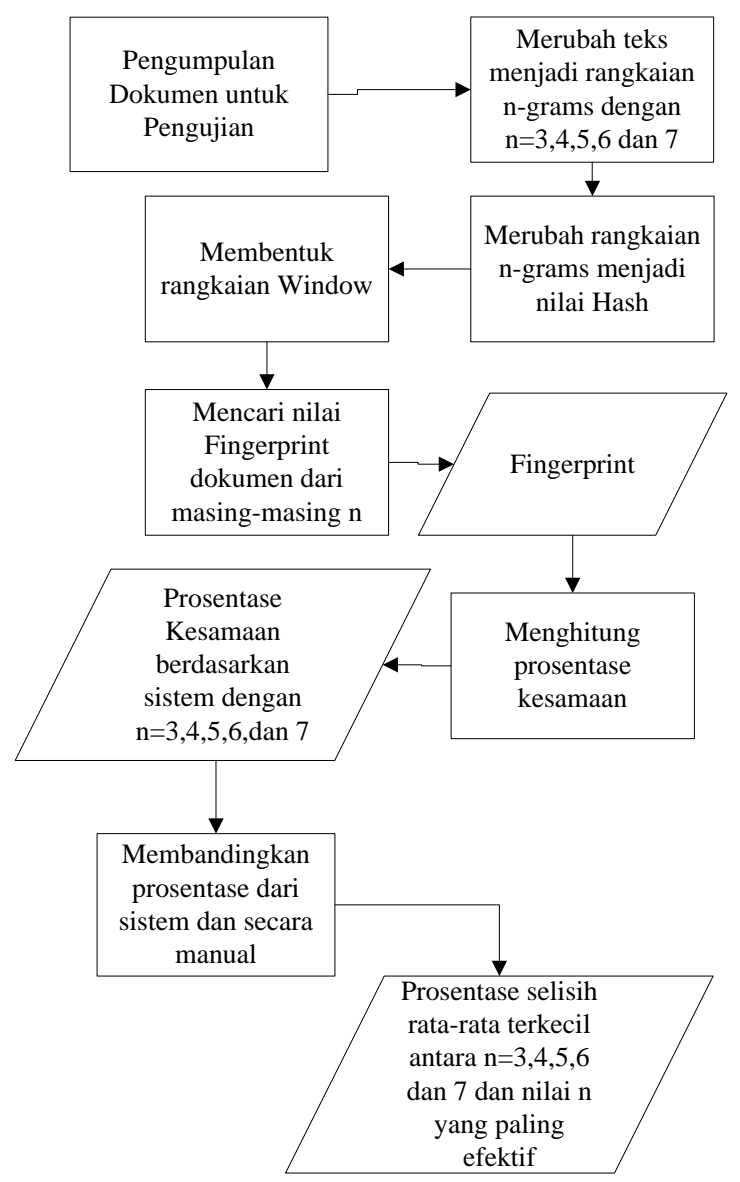

Gambar 1. Tahapan Penelitian

\subsection{Pengumpulan Dokumen Pengujian}

Pengumpulan dokumen digunakan sebagai dokumen pengujian sistem yang dibuat. Dokumen pengujian sistem deteksi indikasi plagiarisme menggunakan dokumen skripsi mahasiswa sebanyak 37 dokumen.

\subsection{Olah Data Dokumen}

Olah data digunakan dalam mengolah permasalahan yang ada dan diimplementasikan pada sistem, Pengimplementasian proses pengolahan data menggunakan bahasa pemrograman PHP. Tahapan dalam deteksi indikasi plagiarisme pada penelitian ini sebagai berikut:

a. Preprocessing

Proses ini diawali dengan merubah isi teks menjadi huruf kecil lalu proses tokenizing dengan merubah rangkaian kalimat menjadi rangkaian kata (7). Kemudian menghapus kata yang tidak relevan diantaranya dan, di, dan sebagainya atau disebut stopword removal (8). Selanjutnya stemming bahasa Indonesia untuk mendapatkan kata dasar. Teknik stemming yang digunakan yaitu teknik Nazief dan Adriani, dengan tingkat kebenaran 93\% dibandingkan teknik stemming bahasa Indonesia dari Vega, Arifin\&Setiono (9). Kata dasar tersebut didapatkan dengan menghilangkan imbuhan yang ada, kemudian digunakan dalam membentuk rangkaian $n$-grams.

b. Analisa Algoritma N-Grams

Algoritma $n$-grams merupakan salah satu algoritma yang digunakan untuk memisahkan teks menjadi rangkaian kata dengan panjang atau $n$ yang ditentukan (10). Panjang $n$ dimulai dari $n=1$ sampai tak terhinga. Contoh rangkaian $n$-grams dari kata "makan minum", dengan $n=4$ akan menjadi "maka, akan, kanm, anmi, nmin, minu, inum".

Rangkaian n-grams dibentuk dengan diawali dari menghilangkan spasi pada rangkaian kata dasar, kemudian pembentukan $n$-grams menurut panjang $n$. Sistem pada penelitian ini menggunakan $n=3, n=4, n=5, n=6, n=7$ untuk mendapatkan nominal $n$ yang paling efektif digunakan dalam pengecekan indikasi plagiarisme. 
c. Perhitungan Hashing

Hashing merupakan suatu metode yang dilkukan untuk merubah nilai $n$-grams menjadi nilai angka yang digunakan dalam algoritma winnowing. Rumus yang digunakan dalam perhitungan hashing pada penelitian ini adalah Rolling Hash. Berikut rumus dari rolling hash (5) seperti rumus 1 berikut:

$H_{\left(C_{1 \ldots C_{n}}\right)}=C_{1} * b^{(n-1)}+C_{2} * b^{(n-2)}+\cdots+C_{(n-1)} * b^{(n)}+C_{n}$

Berdasarkan rumus 1, diketahui c yaitu bilangan ASCII dari karakter, $\mathrm{b}=$ bilangan prima yang ditentukan, dan $\mathrm{n}=$ panjang $n$-grams. Untuk rumus kedua digunakan pada $n$-grams kedua dan seterusnya, dikarenakan tidak memerlukan penghitungan karakter pertama. Berikut rumus kedua roliing hash, seperti pada rumus 2 berikut:

$H_{\left(C_{2 \ldots} \ldots c_{n+1}\right)}=\left(H_{\left(C_{1} \ldots C_{n}\right)}-C_{1} * b^{(n-1)}\right) * b+C_{(n+1)}$

Nilai bilangan prima dalam rumus rolling hash yaitu $\mathrm{b}=3$, mengambil nominal ASCII dari karakter (c). Contoh hasil nilai hash dari rangkaian $n$-grams seperti berikut: [4234, 3983, 4201, 4041, 4376, 4335, 4285]

d. Menentukan Fingerprint

Proses menentukan fingerprint menggunakan algoritma winnowing diawali dengan merubah nilai hash menjadi rangkaian hash berdasarkan nilai window (w). Selanjutnya dipilih nilai hash terkecil dari setiap window. Selanjutnya dilakukan pengecekan apabila ada nilai hash yang sama maka hanya di ambil salah satu. Penelitian ini menggunakan nilai $w=5$, contoh rangkaian window seperti berikut :

[4234 3983420140414376$]$ [3983 420140414376 4335] [4201 404143764335 4285]

Kemudian mencari nilai fingerprint, nilai fingerprint dokumen digunakan untuk membandingkan dengan dokumen lain sehingga didapatkan hasil kemiripan dokumen. Hash terkecil dari setiap window diambil sebagai fingerprint dokumen. Contoh mendapatkan fingerprint dalam window, seperti berikut :

[4234 3983420140414376$]$ [3983 420140414376 4335] [4201 404143764335 4285]

Berdasarkan hasil diatas, diketahui nilai fingerprint yaitu :[3983 4041]

e. Menghitung Kesamaan Kata

Jaccard Coefficient merupakan salah satu metode yang digunakan untuk menghitung kesamaan data (11). Berikut rumus dari metode jaccard coefficient:

$J\left(S_{1}, S_{2}\right)=\frac{\left|S_{1} \cap S_{2}\right|}{\left|S_{1} \cup S_{2}\right|}$

Berdasarkan pada rumus 3 dapat dijelaskan bahwa $S_{1} \cap S_{2}$ merupakan jumlah nilai yang sama antara $\mathrm{S} 1$ dan $\mathrm{S} 2$. Sedangkan $\mathrm{S}_{1} \cup \mathrm{S}_{2}$ merupakan gabungan keduanya. Hasil dari rumus Jaccard Coefficient didapatkan prosentase kesamaan kata.

\section{HASIL DAN PEMBAHASAN}

\subsection{Arsitektur Sistem}

Secara umum arsitektur sistem dalam penelitian ini terdiri dari beberapa proses, seperti yang sudah digambarkan pada gambar 2 berikut: 


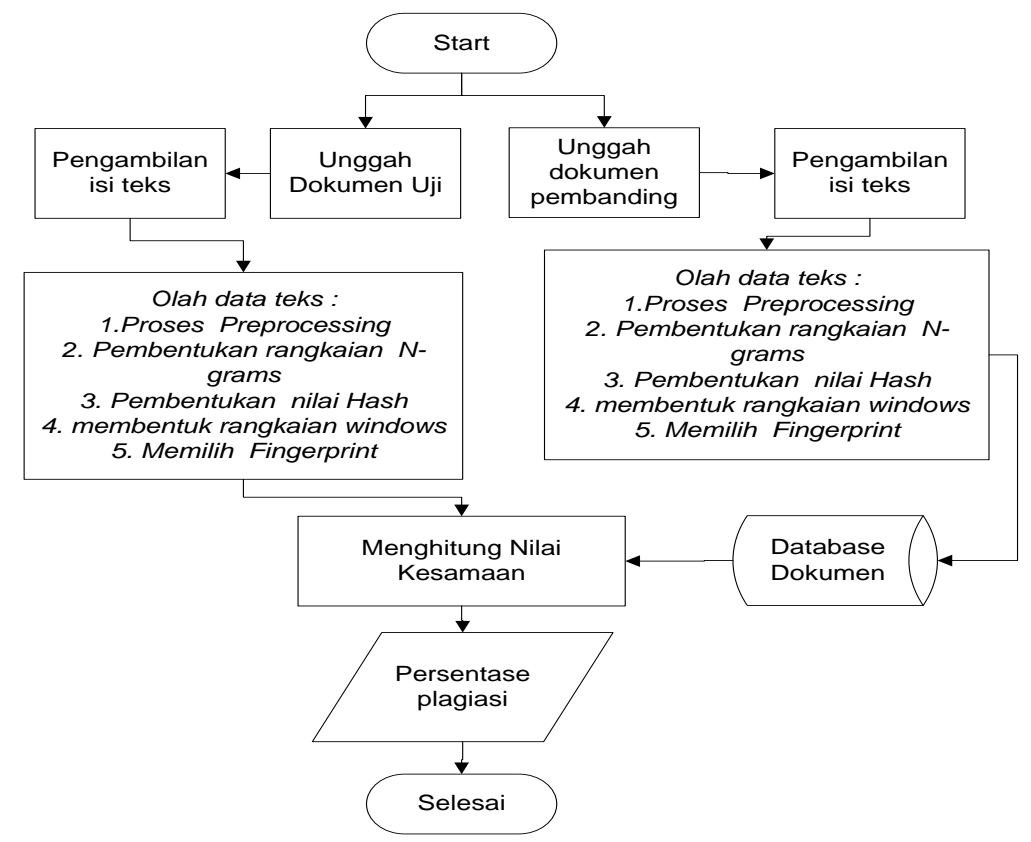

Gambar 2. Arsitektur Sistem

Berdasarkan alur proses sistem pada Gambar 2 diawali dengan unggah file dokumen untuk pembanding lalu didapatkan isi teks, proses preprocessing yaitu dilakukan tokenizing (mengubah kalimat menjadi rangkaian kata), menghilangkan stopword atau menghapus kata tidak relevan kemudian stemming untuk mendapatkan kata dasar, selanjutnya pembentukan n-grams dari hasil preprocessing, mendapatkan nilai hash dari hasil proses sebelumnya, membentuk windowing dan mencari nilai fingerprint lalu disimpan dalam basis data dan digunakan untuk membandingkan dengan hasil dokumen uji.

Langkah selanjutnya mengunggah dokumen uji, dan melakukan proses preprocessing sampai mendapatkan nilai fingerprint. kemudian dilakukan pengecekan dengan membandingkan fingerprint dokumen pembanding dan uji untuk mendapatkan prosentase kesamaan kata antar dokumen.

\subsection{Kriteria Perangkat Lunak}

Spesifikasi perangkat lunak yang digunakan pada penelitian ini dalam mengembangkan sistem, seperti berikut :
a. XAMPP 5.6.11 2013
b. Notepad++
c. HeidiSQL
d. Google Chrome

\subsection{Desain Basis Data (Database)}

Database digunakan untuk menyimpan hasil fingerprint dokumen pembanding pada sistem ini. Basis data yang digunakan yaitu DBMS mysql. Nilai fingerprint yang disimpan digunakan dalam perulangan pengecekan. Berikut atribut database dalam sistem pada tabel berikut:

Tabel 1. Atribut database

\begin{tabular}{ccc}
\hline Nomor & Atribut & Data Type \\
\hline 1 & id_dokumen (Primary Key) & int(11) Auto_Increment \\
2 & nama_dokumen & varchar(50) \\
3 & tipe_dokumen & varchar(50) \\
4 & ukuran_dokumen & 11 \\
5 & fingerprint_dokumen & varchar(10000) \\
6 & tanggal_unggah & timestamp \\
\hline
\end{tabular}




\subsection{Tampilan User Interfaces}

Sistem pada penelitian ini menggunakan tampilan interface sehingga memudahkan saat menggunakan fungsi sistem. Sistem ini mempunyai beberapa menu, yang pertama adalah halaman menu beranda. Menu kedua yaitu menu Unggah Dokumen yang terdapat form unggah file dokumen untuk pembanding. Hasil pengunggahan yaitu didapatkan nilai fingerprint dan disimpan di database. Berikut tampilan menu Unggah Dokumen seperti Gambar 3 berikut:

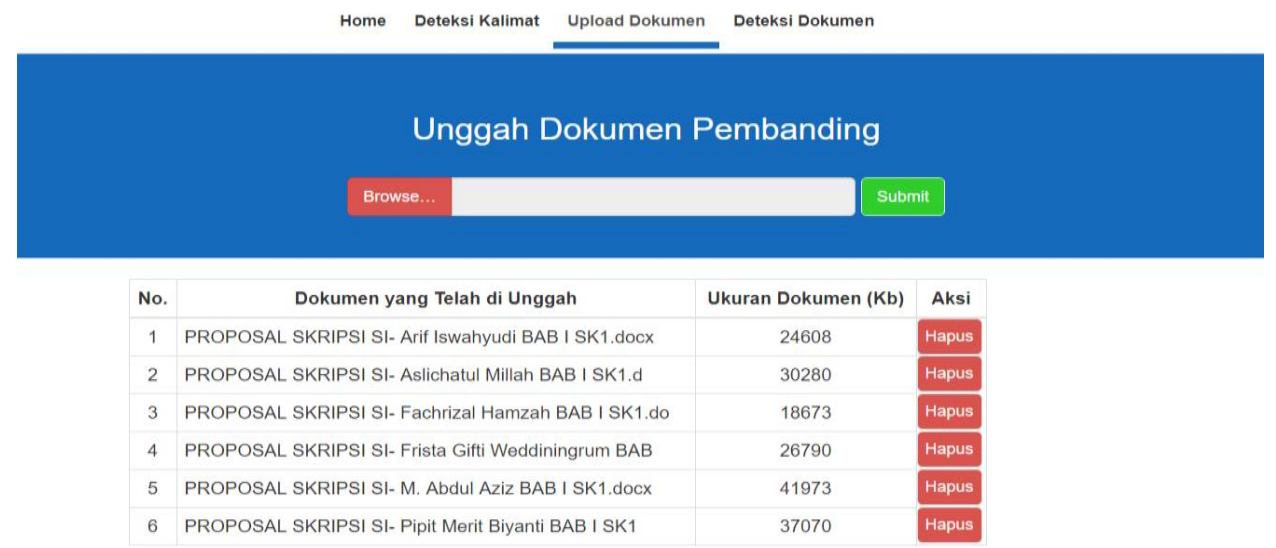

\section{Gambar 3. Halaman Upload Dokumen Pembanding}

Menu ketiga yaitu menu Deteksi Dokumen, menampilkan form untuk unggah dokumen uji, untuk mendapatkan prosentase kesamaan kata. Berikut tampilan menu deteksi dokumen seperti Gambar 4 berikut

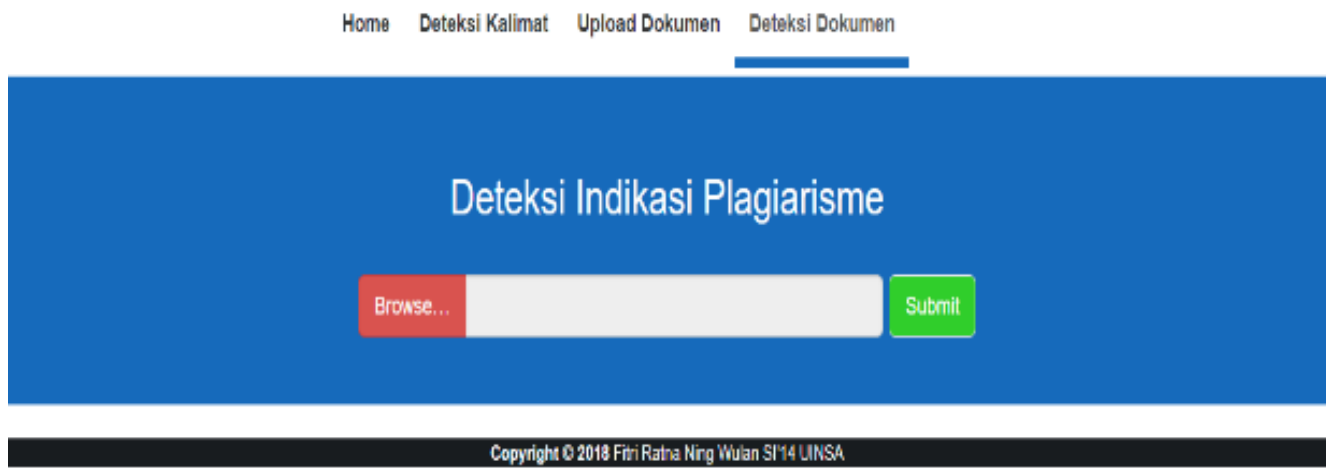

\section{Gambar 4. Halaman Deteksi Kesamaan Kata}

Selanjutnya pada halaman deteksi kesamaan kata sistem akan memproses pengecekan untuk mendapatkan hasil prosentase tingkat kesamaan antar dokumen.

\subsection{Pengujian}

Pengujian pada penelitian ini menggunakan skenario yang sebelumnya sudah dibuat. Berikut skenario digunakan diantaranya:

a. Skenario 1 (pengujian untuk dokumen yang tidak sama)

Skenario 1 diawali dengan mengambil dokumen uji dan pembanding. Proses pengujian dengan mengambil 1 paragraf teks dokumen pembanding dan dimasukkan ke dokumen uji, untuk membuktikan sistem dapat melakukan deteksi plagiasi berdasarkan kondisi memiliki sedikit kesamaan antara 2 dokumen. Berikut tabel pengujian secara manual pada tabel 2: 
Tabel 2. Pengujian Manual Skenario 1

\begin{tabular}{ccc}
\hline Dokumen ke- & kata & Persentase Manual \\
\hline 1 & 69 dari 897 & $7,69 \%$ \\
2 & 62 dari 897 & $6,91 \%$ \\
3 & 93 dari 897 & $10,37 \%$ \\
4 & 52 dari 897 & $5,80 \%$ \\
5 & 53 dari 897 & $5,91 \%$ \\
6 & 111 dari 897 & $12,37 \%$ \\
7 & 77 dari 897 & $8,58 \%$ \\
8 & 56 dari 897 & $6,24 \%$ \\
9 & 53 dari 897 & $5,91 \%$ \\
10 & 109 dari 897 & $12,15 \%$ \\
11 & 42 dari 897 & $4,68 \%$ \\
12 & 35 dari 897 & $3,90 \%$ \\
\hline
\end{tabular}

Dokumen uji untuk skenario 1 menggunakan 1 dokumen, untuk dokumen pembanding menggunakan 12 dokumen. Berikut hasil pengujian skenario 1 untuk $n=3, n=4, n=5, n=6$ dan $n=7$ seperti pada tabel berikut:

Tabel 3. Skenario $1 \mathbf{n = 3}$

\begin{tabular}{cccc}
\hline Dokumen ke- & Prosentase Sistem & Prosentase Manual & Selisih \\
\hline 1 & $43,79 \%$ & $7,69 \%$ & $36,10 \%$ \\
2 & $46,98 \%$ & $6,91 \%$ & $40,07 \%$ \\
3 & $54,92 \%$ & $10,37 \%$ & $44,55 \%$ \\
4 & $53,47 \%$ & $5,80 \%$ & $47,67 \%$ \\
5 & $65,40 \%$ & $5,91 \%$ & $59,49 \%$ \\
6 & $54,80 \%$ & $12,37 \%$ & $42,43 \%$ \\
7 & $47,77 \%$ & $8,58 \%$ & $39,19 \%$ \\
8 & $55,20 \%$ & $6,24 \%$ & $48,96 \%$ \\
9 & $61,25 \%$ & $5,91 \%$ & $55,34 \%$ \\
10 & $58,68 \%$ & $12,15 \%$ & $46,53 \%$ \\
11 & $55,65 \%$ & $4,68 \%$ & $50,97 \%$ \\
12 & $54,06 \%$ & $3,90 \%$ & $50,16 \%$ \\
\hline \multicolumn{4}{c}{ Total } \\
\hline \multicolumn{4}{c}{}
\end{tabular}

Tabel 3 menggambarkan hasil pengujian pada skenario 1 dengan $n=3$, ketika semua selisih dijumlah didapatkan hasil 561,46\% lalu dibagi dengan jumlah dokumen yaitu 12, maka didapatkan rata-rata selisih $46,79 \%$. Untuk $n=4$ dijelaskan pada tabel 4 berikut:

Tabel 4. Skenario $1 \mathrm{n}=4$

\begin{tabular}{cccc}
\hline Dokumen ke- & Prosentase Sistem & Prosentase Manual & Selisih \\
\hline 1 & $40,29 \%$ & $7,69 \%$ & $32,60 \%$ \\
2 & $45,50 \%$ & $6,91 \%$ & $38,59 \%$ \\
3 & $49,80 \%$ & $10,37 \%$ & $39,43 \%$ \\
4 & $48,53 \%$ & $5,80 \%$ & $42,73 \%$ \\
5 & $53,75 \%$ & $5,91 \%$ & $47,84 \%$ \\
6 & $49,85 \%$ & $12,37 \%$ & $37,48 \%$ \\
7 & $49,04 \%$ & $8,58 \%$ & $40,46 \%$ \\
8 & $51,29 \%$ & $6,24 \%$ & $45,05 \%$ \\
9 & $53,83 \%$ & $5,91 \%$ & $47,92 \%$ \\
10 & $57,14 \%$ & $12,15 \%$ & $44,99 \%$ \\
11 & $53,09 \%$ & $4,68 \%$ & $48,41 \%$ \\
12 & $49,17 \%$ & $3,90 \%$ & $45,27 \%$ \\
\hline \multicolumn{4}{c}{ Total } \\
\hline
\end{tabular}

Tabel 4 menggambarkan hasil pengujian pada skenario 1 dengan $n=4$, ketika semua selisih dijumlah didapatkan hasil 510,77\% lalu dibagi dengan jumlah dokumen yaitu 12, maka didapatkan rata-rata selisih $42,56 \%$. Untuk $n=5$ dijelaskan pada tabel 5 berikut: 
Tabel 5. Skenario $1 \mathbf{n}=\mathbf{5}$

\begin{tabular}{cccc}
\hline Dokumen ke- & Prosentase Sistem & Prosentase Manual & Selisih \\
\hline 1 & $30,22 \%$ & $7,69 \%$ & $22,53 \%$ \\
2 & $32,30 \%$ & $6,91 \%$ & $25,39 \%$ \\
3 & $35,55 \%$ & $10,37 \%$ & $25,18 \%$ \\
4 & $31,36 \%$ & $5,80 \%$ & $25,56 \%$ \\
5 & $34,10 \%$ & $5,91 \%$ & $28,19 \%$ \\
6 & $35,40 \%$ & $12,37 \%$ & $23,03 \%$ \\
7 & $38,45 \%$ & $8,58 \%$ & $29,87 \%$ \\
8 & $35,27 \%$ & $6,24 \%$ & $29,03 \%$ \\
9 & $35,18 \%$ & $5,91 \%$ & $29,27 \%$ \\
10 & $37,17 \%$ & $12,15 \%$ & $25,02 \%$ \\
11 & $38,62 \%$ & $4,68 \%$ & $33,94 \%$ \\
12 & $34,21 \%$ & $3,90 \%$ & $30,31 \%$ \\
\hline \multicolumn{4}{c}{ Total } \\
\hline \multicolumn{4}{c}{}
\end{tabular}

Tabel 5 menggambarkan hasil pengujian pada skenario 1 dengan $n=5$, ketika semua selisih dijumlah didapatkan hasil 327,32\% lalu dibagi dengan jumlah dokumen yaitu 12, maka didapatkan rata-rata selisih $27,28 \%$. Untuk $n=6$ dijelaskan pada tabel 6 berikut:

Tabel 6. Skenario $1 \mathrm{n}=6$

\begin{tabular}{cccc}
\hline Dokumen ke- & Prosentase Sistem & Prosentase Manual & Selisih \\
\hline 1 & $16,39 \%$ & $7,69 \%$ & $8,70 \%$ \\
2 & $17,91 \%$ & $6,91 \%$ & $11,00 \%$ \\
3 & $18,77 \%$ & $10,37 \%$ & $8,40 \%$ \\
4 & $17,36 \%$ & $5,80 \%$ & $11,56 \%$ \\
5 & $17,03 \%$ & $5,91 \%$ & $11,12 \%$ \\
6 & $20,10 \%$ & $12,37 \%$ & $7,73 \%$ \\
7 & $20,51 \%$ & $8,58 \%$ & $11,93 \%$ \\
8 & $17,88 \%$ & $6,24 \%$ & $11,64 \%$ \\
9 & $19,49 \%$ & $5,91 \%$ & $13,58 \%$ \\
10 & $21,46 \%$ & $12,15 \%$ & $9,31 \%$ \\
11 & $19,51 \%$ & $4,68 \%$ & $14,83 \%$ \\
12 & $16,52 \%$ & $3,90 \%$ & $12,62 \%$ \\
\hline \multicolumn{4}{c}{ Total } \\
\hline \multicolumn{4}{c}{}
\end{tabular}

Tabel 6 menggambarkan hasil pengujian pada skenario 1 dengan $n=6$, ketika semua selisih dijumlah didapatkan hasil 132,42\% lalu dibagi dengan jumlah dokumen yaitu 12, maka didapatkan rata-rata selisih $11,04 \%$. Untuk $n=7$ dijelaskan pada tabel 7 berikut:

Tabel 7. Skenario $1 \mathbf{n}=7$

\begin{tabular}{cccc}
\hline Dokumen ke- & Prosentase Sistem & Prosentase Manual & Selisih \\
\hline 1 & $9,31 \%$ & $7,69 \%$ & $1,62 \%$ \\
2 & $8,54 \%$ & $6,91 \%$ & $1,63 \%$ \\
3 & $12,17 \%$ & $10,37 \%$ & $1,80 \%$ \\
4 & $9,79 \%$ & $5,80 \%$ & $3,99 \%$ \\
5 & $10,10 \%$ & $5,91 \%$ & $4,19 \%$ \\
6 & $13,40 \%$ & $12,37 \%$ & $1,03 \%$ \\
7 & $11,70 \%$ & $8,58 \%$ & $3,12 \%$ \\
8 & $8,79 \%$ & $6,24 \%$ & $2,55 \%$ \\
9 & $10,33 \%$ & $5,91 \%$ & $4,42 \%$ \\
10 & $12,83 \%$ & $12,15 \%$ & $0,68 \%$ \\
11 & $10,58 \%$ & $4,68 \%$ & $5,90 \%$ \\
12 & $9,86 \%$ & $3,90 \%$ & $5,96 \%$ \\
\hline \multicolumn{4}{c}{ Total } \\
\hline \multicolumn{5}{c}{ Selisih } \\
\hline
\end{tabular}


Tabel 7 menggambarkan hasil pengujian pada skenario 1 dengan $n=7$, ketika semua selisih dijumlah didapatkan hasil 36,89\% lalu dibagi dengan jumlah dokumen yaitu 12, maka didapatkan rata-rata selisih $3,07 \%$.

Setelah dilakukan pengujian baik secara sistem maupun manual pada dokumen seperti pada tabel pengujian dengan $n=3-n=7$ diatas, didapatkan hasil nilai $n$ terbaik dalam mendeteksi kesamaan kata antar dokumen yaitu $n=7$ dengan prosentase rata-rata selisih 3,07\%.

b. Skenario 2 (Pengujian untuk dokumen $100 \%$ sama)

Skenario 2 diawali dengan mengambil dokumen uji dan pembanding. Proses pengujian dengan menyalin semua isi dari salah satu dokumen pembanding menjadi dokumen uji.

Dokumen testing untuk skenario 2 menggunakan 1 dokumen skripsi, untuk dokumen pembanding menggunakan 11 dokumen. Setelah dilakukan pengujian baik secara sistem maupun manual pada dokumen skripsi, didapatkan hasil bahwa semua pengujian dari nilai $n=3$ sampai $n=7$ mampu mendeteksi kesamaan $100 \%$. Seperti dijelaskan pada gambar 8 berikut:

Tabel 8. Pengujian skenario $2 \mathrm{n}=3, \mathrm{n}=4, \mathrm{n}=5, \mathrm{n}=6$ dan $\mathrm{n}=7$

\begin{tabular}{cccccc}
\hline Dokumen $\boldsymbol{k e}$ - & $\boldsymbol{n = 3}$ & $\boldsymbol{n = 4}$ & $\boldsymbol{n = 5}$ & $\boldsymbol{n = 6}$ & $\boldsymbol{n = 7}$ \\
\hline 1 & $60,67 \%$ & $45,27 \%$ & $23,82 \%$ & $11,59 \%$ & $4,62 \%$ \\
2 & $58,87 \%$ & $42,86 \%$ & $24,19 \%$ & $10,52 \%$ & $5,01 \%$ \\
3 & $61,60 \%$ & $39,78 \%$ & $23,77 \%$ & $11,02 \%$ & $4,88 \%$ \\
4 & $54,20 \%$ & $42,63 \%$ & $25,30 \%$ & $12,11 \%$ & $5,88 \%$ \\
5 & $\mathbf{1 0 0 , 0 0 \%}$ & $\mathbf{1 0 0 , 0 0 \%}$ & $\mathbf{1 0 0 , 0 0 \%}$ & $\mathbf{1 0 0 , 0 0 \%}$ & $\mathbf{1 0 0 , 0 0 \%}$ \\
6 & $54,60 \%$ & $42,98 \%$ & $25,21 \%$ & $11,51 \%$ & $4,92 \%$ \\
7 & $57,34 \%$ & $44,16 \%$ & $25,72 \%$ & $11,80 \%$ & $5,65 \%$ \\
8 & $56,91 \%$ & $44,77 \%$ & $24,07 \%$ & $11,14 \%$ & $5,22 \%$ \\
9 & $40,55 \%$ & $36,10 \%$ & $20,87 \%$ & $10,43 \%$ & $5,30 \%$ \\
10 & $58,22 \%$ & $43,94 \%$ & $24,40 \%$ & $10,68 \%$ & $4,54 \%$ \\
11 & $52,04 \%$ & $37,13 \%$ & $20,17 \%$ & $9,50 \%$ & $4,51 \%$ \\
\hline
\end{tabular}

Berdasarkan pemaparan pada tabel 8, dapat disimpulkan bahwa sistem mampu mendeteksi 100\% kesamaan dengan $n=3$ sampai $n=7$.

c. Skenario 3 (Pengujian untuk dokumen sebagian sama)

Pengujian skenario 3 bertujuan untuk membuktikan sistem dapat melakukan deteksi indikasi plagiasi dengan sebagian sama. Pengujian skenario 3 diawali dengan mengambil beberapa paragraf teks dari dokumen pembanding dan meletakkannya di dokumen uji. Berikut tabel pengujian secara manual pada tabel 9:

Tabel 9. Pengujian Manual skenario 3

\begin{tabular}{ccc}
\hline Dokumen Ke- & kata & Persentase Manual \\
\hline 1 & $105 \mathrm{dr} 1653$ & $6,35 \%$ \\
2 & $69 \mathrm{dr} 1653$ & $4,17 \%$ \\
3 & $298 \mathrm{dr} 1653$ & $18,03 \%$ \\
4 & $251 \mathrm{dr} 1653$ & $15,18 \%$ \\
5 & $179 \mathrm{dr} 1653$ & $10,83 \%$ \\
6 & $84 \mathrm{dr} 1653$ & $5,08 \%$ \\
7 & $263 \mathrm{dr} 1653$ & $15,91 \%$ \\
8 & $95 \mathrm{dr} 1653$ & $5,74 \%$ \\
9 & $40 \mathrm{dr} 1653$ & $2,42 \%$ \\
10 & $31 \mathrm{dr} 1653$ & $1,88 \%$ \\
11 & $40 \mathrm{dr} 1653$ & $2,42 \%$ \\
12 & $60 \mathrm{dr} 1653$ & $3,63 \%$ \\
\hline
\end{tabular}

Dokumen uji untuk skenario 3 menggunakan 1 dokumen, untuk dokumen pembanding menggunakan 12 dokumen. Berikut hasil pengujian skenario $3 n=3-n=7$ secara sistem dan manual dan hasil selisih keduanya untuk menentukan nominal $n$ paling efektif yang digunakan dalam mendeteki plagiasi seperti pada tabel berikut: 
Tabel 10. Pengujian Skenario $3 \mathbf{n}=3$

\begin{tabular}{cccc}
\hline Dokumen Ke- & Prosentase Sistem & Prosentase Manual & Selisih \\
\hline 1 & $52,55 \%$ & $6,35 \%$ & $46,20 \%$ \\
2 & $55,88 \%$ & $4,17 \%$ & $51,71 \%$ \\
3 & $62,95 \%$ & $18,03 \%$ & $44,92 \%$ \\
4 & $52,48 \%$ & $15,18 \%$ & $37,30 \%$ \\
5 & $60,12 \%$ & $10,83 \%$ & $49,29 \%$ \\
6 & $57,10 \%$ & $5,08 \%$ & $52,02 \%$ \\
7 & $59,93 \%$ & $15,91 \%$ & $44,02 \%$ \\
8 & $52,95 \%$ & $5,74 \%$ & $47,21 \%$ \\
9 & $54,27 \%$ & $2,42 \%$ & $51,85 \%$ \\
10 & $53,06 \%$ & $1,88 \%$ & $51,18 \%$ \\
11 & $53,99 \%$ & $2,42 \%$ & $51,57 \%$ \\
12 & $57,60 \%$ & $3,63 \%$ & $53,97 \%$ \\
\hline \multicolumn{4}{c}{ Total } \\
\hline \multicolumn{4}{c}{ Selisih } \\
\hline
\end{tabular}

Tabel 10 menggambarkan hasil pengujian pada skenario 3 dengan $n=3$, ketika semua selisih dijumlah didapatkan hasil 581,24\% lalu dibagi dengan jumlah dokumen yaitu 12, maka didapatkan rata-rata selisih $48,44 \%$. Untuk $n=4$ dijelaskan pada tabel 11 berikut:

Tabel 11. Pengujian Skenario 3 n=4

\begin{tabular}{cccc}
\hline Dokumen Ke- & Prosentase Sistem & Prosentase Manual & Selisih \\
\hline 1 & $40,09 \%$ & $6,35 \%$ & $33,74 \%$ \\
2 & $46,86 \%$ & $4,17 \%$ & $42,69 \%$ \\
3 & $59,05 \%$ & $18,03 \%$ & $41,02 \%$ \\
4 & $45,65 \%$ & $15,18 \%$ & $30,47 \%$ \\
5 & $55,54 \%$ & $10,83 \%$ & $44,71 \%$ \\
6 & $50,54 \%$ & $5,08 \%$ & $45,46 \%$ \\
7 & $51,90 \%$ & $15,91 \%$ & $35,99 \%$ \\
8 & $52,18 \%$ & $5,74 \%$ & $46,44 \%$ \\
9 & $52,65 \%$ & $2,42 \%$ & $50,23 \%$ \\
10 & $44,02 \%$ & $1,88 \%$ & $42,14 \%$ \\
11 & $51,19 \%$ & $2,42 \%$ & $48,77 \%$ \\
12 & $50,76 \%$ & $3,63 \%$ & $47,13 \%$ \\
\hline \multicolumn{4}{c}{ Total } \\
\hline \multicolumn{4}{c}{ Selisih } \\
\hline
\end{tabular}

Tabel 11 menggambarkan hasil pengujian pada skenario 3 dengan $n=4$, ketika semua selisih dijumlah didapatkan hasil 508,79\% lalu dibagi dengan jumlah dokumen yaitu 12, maka didapatkan rata-rata selisih $42,40 \%$. Untuk $n=5$ dijelaskan pada tabel 12 berikut:

Tabel 12. Pengujian Skenario $3 \mathbf{n}=5$

\begin{tabular}{cccc}
\hline Dokumen Ke- & Prosentase Sistem & Prosentase Manual & Selisih \\
\hline 1 & $28,07 \%$ & $6,35 \%$ & $21,72 \%$ \\
2 & $33,33 \%$ & $4,17 \%$ & $29,16 \%$ \\
3 & $49,43 \%$ & $18,03 \%$ & $31,40 \%$ \\
4 & $34,16 \%$ & $15,18 \%$ & $18,98 \%$ \\
5 & $42,86 \%$ & $10,83 \%$ & $32,03 \%$ \\
6 & $36,73 \%$ & $5,08 \%$ & $31,65 \%$ \\
7 & $38,12 \%$ & $15,91 \%$ & $22,21 \%$ \\
8 & $40,67 \%$ & $5,74 \%$ & $34,93 \%$ \\
9 & $39,29 \%$ & $2,42 \%$ & $36,87 \%$ \\
10 & $32,72 \%$ & $1,88 \%$ & $30,84 \%$ \\
11 & $37,14 \%$ & $2,42 \%$ & $34,72 \%$ \\
12 & $38,51 \%$ & $3,63 \%$ & $34,88 \%$ \\
\hline \multicolumn{4}{c}{ Total } \\
\hline
\end{tabular}


Tabel 12 menggambarkan hasil pengujian pada skenario 3 dengan $n=5$, ketika semua selisih dijumlah didapatkan hasil 359,39\% lalu dibagi dengan jumlah dokumen yaitu 12, maka didapatkan rata-rata selisih $29,95 \%$. Untuk $n=6$ dijelaskan pada tabel 13 berikut:

Tabel 13. Pengujian Skenario 3 n=6

\begin{tabular}{cccc}
\hline Dokumen Ke- & Prosentase Sistem & Prosentase Manual & Selisih \\
\hline 1 & $16,35 \%$ & $6,35 \%$ & $10,00 \%$ \\
2 & $16,24 \%$ & $4,17 \%$ & $12,07 \%$ \\
3 & $32,62 \%$ & $18,03 \%$ & $14,59 \%$ \\
4 & $23,85 \%$ & $15,18 \%$ & $8,67 \%$ \\
5 & $27,38 \%$ & $10,83 \%$ & $16,55 \%$ \\
6 & $22,54 \%$ & $5,08 \%$ & $17,46 \%$ \\
7 & $26,14 \%$ & $15,91 \%$ & $10,23 \%$ \\
8 & $22,10 \%$ & $5,74 \%$ & $16,36 \%$ \\
9 & $22,18 \%$ & $2,42 \%$ & $19,76 \%$ \\
10 & $17,72 \%$ & $1,88 \%$ & $15,84 \%$ \\
11 & $20,46 \%$ & $2,42 \%$ & $18,04 \%$ \\
12 & $19,89 \%$ & $3,63 \%$ & $16,26 \%$ \\
\hline \multicolumn{4}{c}{ Total } \\
\hline \multicolumn{4}{c}{ Selisih } \\
\hline
\end{tabular}

Tabel 13 menggambarkan hasil pengujian pada skenario 3 dengan $n=6$, ketika semua selisih dijumlah didapatkan hasil 175,83\% lalu dibagi dengan jumlah dokumen yaitu 12, maka didapatkan rata-rata selisih $14,65 \%$. Untuk $n=7$ dijelaskan pada tabel 14 berikut:

Tabel 14. Pengujian Skenario $3 \mathrm{n}=7$

\begin{tabular}{cccc}
\hline Dokumen Ke- & Prosentase Sistem & Prosentase Manual & Selisih \\
\hline 1 & $10,57 \%$ & $6,35 \%$ & $4,22 \%$ \\
2 & $8,71 \%$ & $4,17 \%$ & $4,54 \%$ \\
3 & $24,48 \%$ & $18,03 \%$ & $6,45 \%$ \\
4 & $17,43 \%$ & $15,18 \%$ & $2,25 \%$ \\
5 & $17,59 \%$ & $10,83 \%$ & $6,76 \%$ \\
6 & $13,07 \%$ & $5,08 \%$ & $7,99 \%$ \\
7 & $19,70 \%$ & $15,91 \%$ & $3,79 \%$ \\
8 & $11,71 \%$ & $5,74 \%$ & $5,97 \%$ \\
9 & $9,76 \%$ & $2,42 \%$ & $7,34 \%$ \\
10 & $8,37 \%$ & $1,88 \%$ & $6,49 \%$ \\
11 & $9,25 \%$ & $2,42 \%$ & $6,83 \%$ \\
12 & $7,87 \%$ & $3,63 \%$ & $4,24 \%$ \\
\hline \multicolumn{4}{c}{ Total } \\
\hline
\end{tabular}

Tabel 14 menggambarkan hasil pengujian pada skenario 3 dengan $n=7$, ketika semua selisih dijumlah didapatkan hasil 66,87\% lalu dibagi dengan jumlah dokumen yaitu 12, maka didapatkan rata-rata selisih $5,57 \%$.

Setelah dilakukan pengujian skenario 3 dengan $n=3$ sampai $n=7$ pada tabel 10 - tabel 14 , didapatkan hasil nilai $n$ terbaik yang digunakan dalam mendeteksi kesamaan kata antar dokumen adalah $n=7$ dan prosentase rata-rata selisih (akurasi) 5,57\%.

Berdasarkan pengujian yang telah dilakukan, diambil prosentase selisih rata-rata terkecil dari setiap skenario dan didapatkan nilai $n$ berdasarkan nilai selisih rata-rata terkecil, nilai $n$ tersebut merupakan yang paling efektif ketika digunakan dalam proses deteksi plagiasi. Pada gambar grafik berikut menunjukkan prosentase rata-rata terkecil dari setiap skenario, seperti berikut : 


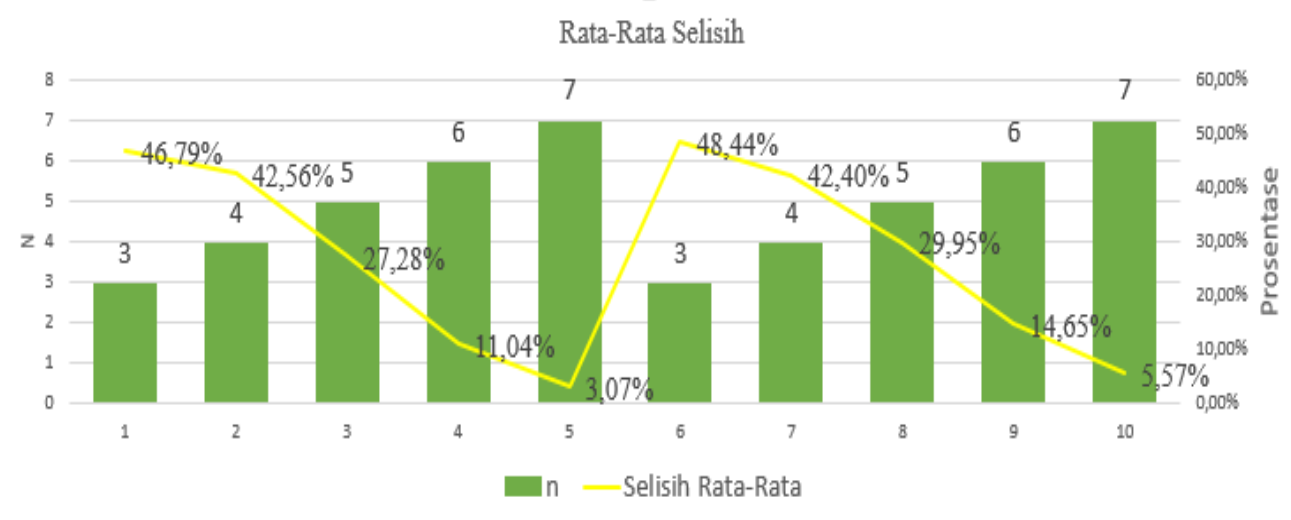

Gambar 5. Grafik Hasil Rata-Rata Selisih

Grafik pada Gambar 5 menggambarkan $n=7$ merupakam nilai yang paling efektif pada skenario 1 dan 3. Untuk rata-rata selisih pada skenario 1 dengan prosentase 3,07\% dan skenario 3 dengan rata-rata selisih prosentase 5,57\%. Berdasarkan hasil pengujian dapat disimpulkan semakin kecil nilai $n$ maka semakin tinggi prosentase kesamaan, sebaliknya semakin besar nilai $n$ maka semakin rendah prosentase kesamaan. Tingkat prosentase dan waktu eksekusi juga dipengaruhi oleh jumlah kata.

\section{KESIMPULAN}

Berdasarkan hasil pembahasan pada bab-bab sebelumnya maka dapat diambil kesimpulan bahwa:

a) Pengolahan teks saat deteksi dapat menggunakan metode $n$-grams dan winnowing.

b) Berdasarkan pengujian membuktikan bahwa $n=7$ yang paling efektif digunakan dalam pendeteksian plagiasi menurut kesamaan setiap kata..

c) Hasil pengujian dapat membuktikan tingkat prosentase dan waktu eksekusi dipengaruhi oleh jumlah kata. Besar $n$ juga berpengaruh pada prosentase kesamaan.

\section{DAFTAR PUSTAKA}

[1] Dillak RY, Laumal F, Kadja LJ, S S. Sistem Deteksi Dini Plagiarisme Tugas Akhir Mahasiswa Menggunakan Algoritma N-Grams dan Winnowing. J Ilm. 2016;2.

[2] Schleimer S, Wilkerson DS, Aiken A, Berkeley UC. Winnowing: Local Algorithms for Document Fingerprinting.

[3] Lisangan EA. Implementasi n-gram Technique dalam Deteksi Plagiarisme pada Tugas Mahasiswa. 2015;(SEPTEMBER 2013).

[4] Wibowo RK, Hastuti K. Penerapan Algoritma Winnowing Untuk. TechnoCOM. 2016;15(4):303-11.

[5] Setiawan A. Implementasi Algoritma Winnowing Untuk. Pelita Inform Budi Darma. 2017;(1011340):134-8.

[6] Purwitasari D, Kusmawan PY, dkk. Deteksi Keberadaan Kalimat Sama Sebagai Indikasi Penjiplakan Dengan Algoritma Hashing Berbasis N-Gram. 2011;6(1):37-44.

[7] Kao A, Poteet SR. Natural language processing and text mining. Natural Language Processing and Text Mining. 2007. 1-265 p.

[8] Indurkhya N, Damerau FJ. Handbook of Natural Language Processing Second Edition. New York: CRC Press; 2010.

[9] Asian J, Williams HE, Tahaghoghi SMM. Stemming Indonesian. 2005;38.

[10] Hornik K, Mair P, Rauch J, Geiger W, Buchta C. The textcat Package for n -Gram Based Text. 2013;52(6).

[11] Aggarwal CC. Data Mining: The Textbook. New York: Springer; 2015. 